\title{
A Study of East Loloan Communities' Ritual Activities Spoken in Balinese Malay Language
}

\author{
I Nyoman Suparwa ${ }^{1}$, Anak Agung Putu Putra ${ }^{1} \&$ Ni Luh Gede Liswahyuningsih ${ }^{2}$ \\ ${ }^{1}$ Indonesian Language and Literature Study Program, Faculty of Arts, Udayana University, Denpasar, Bali, \\ Indonesia \\ ${ }^{2}$ Indonesian and Balinese Language Education program, Faculty of Language and Art Education, IKIP PGRI Bali, \\ Denpasar, Indonesia \\ Correspondence: I Nyoman Suparwa, Indonesian Language and Literature Study Program, Faculty of Arts, \\ Udayana University, Denpasar, Bali, Indonesia. Tel: 62-817-354-717. E-mail: suparwa_nym@yahoo.co.id
}

Received: January 16, 2020; Accepted: May 26, 2020; Published: May 28, 2020

\begin{abstract}
The purpose of this study was to examine the discourse of Balinese Malay-language rituals activities which includes (a) the structure of discourse, (b) cohesion, (c) metalinguistic analysis, and (d) cultural context; and the dynamics of traditional discourse and Balinese Malay-language culture in the community. This study applied the theory of discourse analysis that viewed the language used in context, which means that people can communicate because they understand discourse (text), context, and patterns or structure. The choice of the informants was by applying the purposive sampling method with certain criteria. The data was obtained through semi-structured interviews. The research location was in East Loloan, as the center of Balinese Malay language speakers. The research findings showed that the discourse of traditional activities and Balinese Malay-language culture used language (microstructure) which was classified as the barrel of an oral language, so that the speech style was clearly visible, both in the structure of discourse, the use of cohesion, and its metalinguistic elements. Meanwhile, in the language (macro structure) it was seen that the use of language for the disclosure of Malay culture that was closely related to Islam/Moslem religion. This could be seen in the co-text of the use of the terms silaturahmi, ngangini, and the context of the use of cultural symbols such as penyingset as a symbol of the men paying attention to and respecting women in traditional customs. Furthermore, in the dynamics of cultural discourse, there appeared to be an attraction between the retention of identity and accommodation in situations and conditions that lead to be changed by the time.
\end{abstract}

Keywords: discourse study, custom activities, balinese malay language

\section{Introduction}

Discourse as a term is not only used in the field of language (linguistics), but also in other fields of study. In linguistics, discourse analysis refers to the study of language units over sentences which focus on a higher level than grammatical relations (Prasetyo, 2016). Balinese Malay language has linguistic characteristics (microlinguistics) and outside languages(macolinguistics). The specificity of the Balinese Malay language can be viewed by a comparison to the Indonesian language with its development. Aside from the unique language, the Loloan community is also rich in Malay and Islamic customs and culture that is quite thick. Various traditions, customs and culture continue to be carried out until now. The tradition carried out by the Loloan community is applied starting from the birth of an individual until he/ she dies. The importance of sustainability in language research especially the Balinese Malay language studies, particularly in the field of discourse, could contribute to the results of studies in literacy promotion activities.

\section{Problems}

The problem answered in this research is about how is the use of language in the discourse of traditional and cultural activities in Balinese Malay, which includes macro analysis and cultural context, as well as the dynamics that occur in traditional and cultural activities?

\section{Method}

This research was conducted by applying a qualitative approach that emphasizes the naturalness of observation, depth of text data, process-oriented and discovery, inductive, descriptive, explanatory, and dynamic reality 
(Sudaryanto, 1993: 4). In this study, data collection focused on East Loloan Village alone, because the customs and culture of a typical Malay are thicker than the West Loloan Village. In addition, because the native descendants of Loloan live more in East Loloan, while in West Loloan, the population is more migrants from other tribes. In this research, oral data and written data were used. Oral data in the form of direct speech in the use of language, specifically speech about traditional and cultural activities that take place and are applied in the daily lives of the Loloan community, are used as the main data in this study, in addition to dialogue, and others. Then, the written data can be in the form of Malay language writing, such as texts on customs and culture that might be found in the field. The analyzed text is discourse in the form of documented nonfiction stories about traditional Malay culture and activities in Bali which were delivered orally and then transcribed and translated into Indonesian (Attached in this report). There were four ritual activities, such as mekawin 'marriage', potong rambut 'haircuts', mauludan 'Maulud Nabi', and khitanan 'circumcisions'.

\section{Discussions}

The results of the study of the four discourses are presented in two sections according to the problem, namely (a) (micro and macro) analysis of the discourse which includes structure, cohesion, language metafunction, and the context of the situation; as well as the dynamics of the discourse of custom activities and culture in the Malay language of Bali.

\section{A. Marriage}

At the wedding ceremony there are several processions that need to be carried out by the bride and groom and their families. Before the marriage procession, there is a procession known as Ngangini. Ngangini comes from the word angin, which means wind, so the word ngangini can be defined as "to give wind" or "give news". Ngangini intends to give news to the family of the woman that someone will come to propose to the girl. Ngangini could also become a gathering of men's activities for women to ask questions and find out whether the girl to be proposed has already taken or not. Furthermore, after the procession of ngangini is a marriage proposal or known with the term of lamaran. In the lamaran, men will bring several things as present to the women. Thus, the process of ngangini is intended to bring news regarding the choice of the date to officially propose the bride to be. In the past, such process often described as each of the parents performed pantun 'kind of rhyming poems' being spoken reciprocally to one another (if both candidates were Loloan people) (Admin, 2014).

In the proposal phase (lamaran), men brought deliveries in the form of food, fruit, coffee and sugar, to the women known as penyingset and cingkrem. Penyingset comes from singset that means 'tight.' So the meaning of peyingset is the binder given by the male to the female. On the other hand, cingkrem refers to the household items that will be used by the bride and groom. Thus, penyingset is for personal needs used by the brides, while cingkrem is household needs used for both the bride and groom. Both penyingset and cingkrem symbolize the willingness and competence of the men to support the bride.

During the lamaran process, there would be a discussion related to the wedding ceremony. It could be discussing about the place and date of the wedding. The good months are usually chosen, such as the beginning of the month of Rabiul, Rajab, Shawwal, or Dhul-Hijjah in the Hijriyah year. In this procession, they will discuss about the requests or special conditions coming from the women's side. The woman will ask for an amount of money as agreed, or usually called as uang dapur. This certain amount of money is intended to be kind of assistance to the woman to hold the wedding ceremony and also as a tribute to the woman. The nominal of it is determined by the woman. The last procession carried out at this premarital ceremony was called nyelesei 'completing procession'. Nyelesei is derived from the word selesai 'finished' which means 'ending'. In this procession, there is no discussion about uang dapur anymore. This procession is the last step in the initial rituals before the marriage, which consists of handing over the uang dapur, and finalized the date of the marriage.

The marriage contract or in Loloan, known with the term of akad nikah is usually held at the place of the woman's family first or at the KUA (Kantor Urusan Agama/ the Indonesian Religious Affairs Office). If it is involving the elopement, then the akad nikah is usually held at the male side because it is not approved by the family of the female. In some cases, the women are seduced to approve the marriage because the marriage binds two families. If that doesn't work, then use a Muslim judge (wali hakim) from the KUA. In the marriage contract procession, when the groom arrives at the bride's home, there is a ritual, where the groom is showered/thrown by yellow rice containing money called ambur salim. Ambur salim is a term taken from Malay and Arabic. Ambur is a Malay language which means 'to shower or throw' and salim which comes from Arabic 'سالم' means 'survived'. Ambur Salim has the meaning of sharing and asking for salvation for the bride and groom.

Ambur Salim is carried out by showering the yellow rice filling with money. It is usually done by the children, but sometimes all people of all ages participate in it. Rice has the meaning of hope for the bride and groom's in terms 
of being able to fill the need of food later on, and the money in it is a gift or alms of the bride and her family to people for the hope of getting good prayers. After that, both bride and groom move to the altar to do the contract. After the marriage contract, sometime later the bride and groom are invited to the male's family. This procession is called ngunduh mantu. Ngunduh mantu derives from the word ngunduh which means 'to take' (in this case, a daughter-in-law). This procession means that the man is taking the woman as the daughter in law in the family. It is done by taking the bride to the groom house, accompanied by the bride's family as the one who 'deliver/nganter', and the groom's family as the one who 'pick up/nyemput'. When the bride and groom arrive at the house, there will be ambur salim showering ritual before they enter the house.

After completing the procession of ngunduh mantu, the bride goes back to her family house and given such kind of token called pesaluk. The pesaluk is commonly in the form of kitchen utensils and clothes, and women also give men clothes, for example, kind like the piety dress, sarong, and cap. After completing the procession, then both families will discuss where then the bride and groom will stay after the marriage.

\section{B. Mauludan}

Mauludan or maulid nabi activity was held in the early month of Rabiul Awal in the Hijri year. This activity was carried out to celebrate the birth of the Prophet Muhammad. Mauludan comes from the Arabic word, maulid 'مولد' which means 'to be born'. At the time of the birth of this prophet, the Loloan community has a tradition to make a thing called male. Male is the place to lay the decorated eggs. The making of male usually used a banana tree trunk. However, nowadays, the making of male is more modern and the creativity of the community has developed as well. The male symbolizes faith, Islam, and the wisdom of humans and eggs are used because eggs symbolize the early phase of life which also means birth or new life. In this celebration, the eggs in this male will be distributed to the people.

During this maulud, people came to the mosque early in the morning to celebrate, and at this time, there is also another event, on which parents are able to do another religious ritual to save money. The ritual is known as aqeeqa or aqiqah. In this ritual, parents who just got a baby must shave or cut some part of their baby's hair to symbolize the celebration of the newly born. At this time, the elder (religious leader) will recite a prayer called aqidatul Awam. Aqidatul Awam is derived from the Arabic word, aqada 'عقد' which means 'aqeedah' or 'belief' and awam/danamun ' عا' which means 'general/common', 'one who does not know', or 'awam.' Aqidatul awam contains the history of the prophet, from birth, family, until his death and also contains general knowledge about Islam, such as angels. After reciting the aqidatul awam, the elder continues by reading a poem called burdah. The purpose of reading this burdah is for the children who have their hair cut to be given health and safety. After reading the burdah, the eggs in the male will be distributed to people who have gathered at the mosque. This is expected to be a prayer and hope that the children who have had their hair cut could grow in a healthy and safe condition.

\section{Potong Rambut/Cutting Hair}

This haircut ceremony/potong rambut is an activity carried out by parents to their newborn children. Generally, this is done as part of the aqiqah procession. However, along with the times, this haircut ceremony was held in the mosque together during the implementation of the birthday of the Prophet Muhammad. Before aqiqah there was a nelai ceremony. Nelai is a word derived from the Balinese language 'telah' which means arti 'has been used up'. The purpose of this ceremony is to pray for a child who has just broken his navel. Nelai is a ceremony to give names to children by reciting burdah poetry. Burdah comes from the Arabic word barada ' بر' which means 'dingin/cold'. This burdah poem contains praise to the Prophet Muhammad. The reading of this burdah poem is done as a hope that the child will be given safety and be protected from all kinds of distractions.

At the time of the haircut, East Loloan people usually make male, which is a decorated egg, and equipped with a cloth consisting of yellow flour, yellow rice filled with money, and ivory coconut. The eggs are used because they are a symbol of the start of life. In terms of religion, eggs symbolize as a person's faith, and Islam. Through the egg, the child will get all the pray. Meanwhile, in the past, people used duck eggs in the hope that their children would be easily directed. However, along the times and economic needs, nowadays, Loloan people use purebred eggs because it is easier to obtain. The eggs are decorated in pajegan, which underneath are filled with fruits.

This haircut procession begins by reciting the mahallul qiyam. Mahallul qiyam comes from Arabic mahala 'محل' which means 'place' and qiyam 'قي" which means 'to stand'. At the time of this reading, the people who had been invited, were asked to stand up and this means that haircut ceremony is about to begin. The baby that needs the haircut is carried by his parents or relatives and the one who cut the hair is the local religious leaders.

After the hair is cut, the child is swiped with yellow flour by the religious leader who has cut the hair, and later on, the leader will wash his hands with the water of ivory coconut. The coconut fruit is used as a symbol of hope so 
that the child can become like a coconut tree that has many uses. The rice symbolizes the child's living expectations, his food is fulfilled. After that, the rice containing the money was thrown, the rice symbolizes alms. The ritual is known as ambur salim. Ambur means 'to throw', while rice symbolizes fortune and salim means safety. Therefore, the purpose of the ambur salim is to reject reinforcements, asking for safety so that the child is healthy and safe (Mawati, 2016).

\section{Khitanan}

Khitanan or circumcision is a word derived from the Arabic khatana 'ختن' which means 'to cut'. Circumcision means opening or cutting the skin that covers the tip of the genitals in order to be clean from the previous 'unclean' condition. The circumcision is an activity to eliminate some male and female pubic skin.

In the Loloan culture, circumcision for women is held when the child is still a baby, for example, a few days after birth. On the other hand, for boys, the circumcision is done when children are a bit older. In the past, it was generally done when children were around the age of 8-12 years old but in recent times, it was common to circumcise children from the age of five, and also the tools for circumcision used to be razor blades and scissors. Before doing the circumcision procession, the child who will be circumcised will be asked to sit on a coconut that has sprouted.

Coconut is a thousand-use fruit which is a symbol of hope and prayer for parents to make their children useful. Then, the child who will be circumcised is clothed in yellow, dark yellow, or orange cloth and also uses jewellery such as a necklace from brass. This is because the ancestors of the Loloan Malay people loved bright colors, so that the yellow colored cloth was used. While waiting for people to come, there will be pencak silat (Indonesian martial arts) attractions accompanied by drums. In the past

After the part has been cut and bleeding, the coconut fibre will be used to prevent the contact of the cut skin with a cloth. For some time the child must not do any activity and just rest / lay at home. This needs to be done so that the child is cured immediately. It is because too much movement will ruin the foreskin and must repeat the circumcision. Nevertheless, nowadays, the procession becomes more modern, since the children only need to go to the doctor for circumcision and can immediately use pants afterwards.

After returning from circumcision or a doctor, the child needs to be given the same ritual, ambur salim (has been explained in the previous sub-chapter). Afterwards, the child is given the verses of the Al-Qu'ran (holy book) aloud with the aim of protecting him from Satan and all interference. Lastly, people will come to give money to the child. This is done to encourage and please the child.

\section{Results}

The Loloan rituals activities which have been dominated by spoken languages will surely enrich the culture of one's literary culture, because the existence of literature can last hundreds of years. The discourse of traditional and cultural activities in Balinese Malay language is classified as a discourse that has an informative function because the conveyed discourse is intended to provide information to the reader/ community. Related to the informative function, the discourse elements are arranged regularly following the rules that characterize the narrative style.

Structural analysis in the Loloan Malay language shows that not all elements of events were filled in the discourse of traditional culture in Balinese Malay language. In this case, it is found that the elements are title, then, followed by elements of narrative or event, then continued by narrative peak or peak event, followed by narrative post peak or events after the peak, and the element before the end which is called the closure. Finally, the whole story ends with the finishing event or ending. Linguistically, the events in the structure of the discourse are stated in the sentence, except the title stated with the word, for example the title is stated with the word mekawin 'marriage'. Event is stated with the sentence 'kalo nak mekawin tu ade namenye ngangini' "in the marriage procession, there is an event which is called ngangini". Then, the peak event is stated by the group of words akad nikah 'marriage contract'. Furthermore, the event after the peak is expressed in a unit of lingual sentence, that is 'setelah prosesi pernikahan di yang perempuan, kemudian diajak ke rumah yang laki namenye ngunduh mantu' "after the procession of marriage at the woman house, then the bride is invited to the house of the man which is called ngunduh mantu". Finally, the story is closed with a closing event that is contained in the sentence Dua hari tu setelah selesai diajak pulang "Two days after, the bride and groom are being asked to go to the bride's family house and the story is finished by the sentence Terus abis tu benang merah benang putih, dimane die nak diem "then after that, red or white, the decision of where they are going to stay".

In cohesion analysis, the cohesion tool used in constructing the discourse cohesiveness of traditional activities and culture in the Balinese Malay language is by the use of transitional words/ expressions, such as; words/ expressions 
of terus "then", abis tu 'after that', kemudian 'afterwards', and terus abis tu 'then after that '. In addition, another cohesion tool is also used in the discourse, such as: repetition of keywords, such as; the word ngangini 'introduce yourself', yang laki 'the men' and mawa 'bring' are used in certain sentences and are used again in the next sentence. Another cohesion tool is the use of pronouns, such as $n i$ 'this' or $t u$ 'that' which include the demonstrative pronouns and die 'he' which is classified as single 3rd person pronoun.

Metalanguage analysis found in traditional ceremonies of Loloan Malay community, such as; in the marriage culture, dominantly use words/ terms related to marriage, such as mekawin 'marriage', ngangini 'introducing yourself', ngelamar 'proposing ', restu 'approval/ permission in the form of prayer', akad nikah 'marriage contract', KUA 'The Indonesian Religious Affairs Office', penghulu 'headman', prosesi pernikahan 'marriage process', ngunduh mantu 'getting daughter-in-law (on the man's side)', pesaluk 'giving/ gifts', and nganten 'bride and groom'. In the activity of "potong rambut" 'haircut', the words/ terms that are commonly used, such as; motong rambut 'cutting hair', mauludan 'Maulud day celebration', ngekah 'three months' ceremony (aqiqah)', and nelai 'naming'. In the activity of "Maulud Nabi", the used words/ terms are mauludan "celebration of the birthday of the prophet", male "a place of some eggs for ceremony", and mace murdah "reading the burdah". In the activity of Khitanan "Circumcision", the used words/ terms are including mesunat 'having circumcision', ditabur kendang 'beating drum music', atraksi pencak silat 'pencak silat attractions', and diambur salim 'having a ritual'.

Morphological analysis is in the form of basic words used in the discourse, such as restu 'blessing', kopiah 'skullcap', sarung 'sarong', and pesaluk 'kitchen utensils'. Words/ terms that include invented words are mekawin 'marriage', nglamar 'proposing', and penghulu 'headman'. Words belonging to the group of words, such as; akad nikah 'marriage contract', benang merah 'red string', uang dapur 'money for kitchen budget', and baju takwa 'piety dress'. In addition, there are also mixed words/groups of words, between invented words and basic words, such as prosesi pernikahan 'the marriage procession', ngunduh mantu 'proposing daughter in law', and kain setalam 'wrapper cloth'.

Analysis of Macro structure towards traditional discourse in Balinese Malay language discusses the use of verbal and nonverbal symbols. These symbols include Ngangini derived from the word angina 'wind', so the word ngangini is meant to "give wind" or give news. Pengingset comes from the word singset which means 'tight'. Ambur is a Malay language which means 'to scatter or throw' and salim which comes from Arabic which means survived. Nelai is a word derived from the Balinese language 'telah' which means 'used up'.

In the traditional ceremonies of Loloan Malay Community, dynamics of the culture were found in the implementation, such as; the use of rhymes which in the past had always been used during a marriage procession, especially in the process of ngangini, it is now rarely found. Likewise, in the procession of sitting on a coconut when a boy is about to circumcise, in the past, the activity was always carried out, but at this time, the procession has been eliminated.

\section{Conclusion}

Not all elements of events were filled in the discourse of traditional culture in Balinese Malay language. It is found that the elements are title, then, followed by elements of narrative or event, then continued by narrative peak or peak event, followed by narrative post peak or events after the peak, and the element before the end which is called the closure. Finally, the whole story ends with the finishing event or ending. Linguistically, the events in the structure of the discourse are stated in the sentence, except the title stated with the word. The cohesion tool used in constructing the discourse cohesiveness of traditional activities and culture in the Balinese Malay language is by the use of transitional words/ expressions, repetition of keywords, and pronouns. Morphological analysis is in the form of basic words and mixed words/ groups of words, between invented words and basic words, used in the discourse. The analysis of macro structure in the traditional Balinese-Malay rituals discourses discussed above were closely related to the use of verbal and nonverbal symbols. Furthermore, in the East Loloan Malay Community rituals, the dynamics of the culture were found in each of the implementation, such as some of the rituals are eliminated.

\section{References}

Admin, U. (2014). Tradisi kelakat dalam perkawinan masyarakat Muslim kelurahan loloan timur kabupaten Jembrana Bali. Diambil dari. Retrieved from https://www.e-jurnal.com/2014/05/tradisi-kelakat-dalamperkawinan.html

Bali Post. (2018). "Bangkitkan Budaya Literasi Pemuda Loloan Inisiasi Gerakan 30 MB di Rumah Baca". Denpasar.

Mawati. (2016). Ritual Baayun Anak dan Dinamikanya. Almurabbi, 2(2). 
Prasetyo, A. (2016). Pengertian Wacana dan Analisis Wacana. Retrieved from https://www.linguistikid.com/2016/10/ pengertian-wacana-dan-analisis-wacana.html

Sudaryanto. (1993). Metode Linguistik (Bagian Pertama dan Kedua). Yogyakarta: Duta Wacana University Press.

Swarsi, S. (2010). Identitas Budaya Suku Loloan Bali. Retrieved from https://varianwisatabudayasundakecil. blogspot.com/2010/ 05/identitas-budaya-masyarakat-loloan.html

\section{Copyrights}

Copyright for this article is retained by the author(s), with first publication rights granted to the journal.

This is an open-access article distributed under the terms and conditions of the Creative Commons Attribution license (http://creativecommons.org/licenses/by/4.0/). 